\title{
PENGARUH SENAM AEROBIK MIX IMPACT TERHADAP PENURUNAN KADAR LEMAK TUBUH PADA SANGGAR SENAM RAI KOTA SAWAHLUNTO
}

\author{
Asep Sujana Wahyuri \\ ${ }^{1}$ Program Studi Pendidikan Jasmani Kesehatan dan Rekreasi, Fakultas Ilmu Keolahragaan, Universitas \\ Negeri Padang. Jalan Prof. Dr. Hamka Air Tawar Barat, Padang,25132, Indonesia. \\ asepsw.unp@gmail.com
}

\begin{abstract}
Abstrak
Penelitian ini merupakan penelitian eksperimen semu yang bertujuan untuk mengetahui seberapa besar pengaruh senam aerobikmix impact terhadap penurunan kadar lemak tubuh pada sanggar senam Rai Kota Sawahlunto.

Populasi dalam penelitian ini adalah member wanita yang aktifdalamkelassenamaerobik di SanggarSenamRaiKotaSawahluntosebanyak 57 orang. Pengambilan sampel menggunakan teknik purposive sampling dengan sampel berjumlah 14 orang. Hipotesis yang diajukan dalam penelitian ini adalah pengaruh signifikan senam aerobikmix impact terhadap penurunan kadar lemak tubuh pada sanggar senam Rai Kota Sawahlunto.

Berdasarkan tabel diatas didapatkan nilai $t_{\text {hitung }}=38.00$ sedangkan $t_{\text {tabel }}$ sebesar 1.771 dengan taraf signifikan $\alpha=0.05 \mathrm{dan} \mathrm{dk}=14$ Berdasarkan pengambilan keputusan diatas maka $t_{\text {hitung }}>t_{\text {tabel }}(38>1.771)$. Dapat disimpulkan bahwa adanya efek dari latihan senam aerobikmix impact terhadap penurunan kadar lemak tubuh anggota sanggar senam Rai Sawahlunto.
\end{abstract}

Kata kunci : Senam Aerobik Mix Impact, Kadar Lemak Tubuh

\section{THE EFFECT OF AEROBIC MIX IMPACT ON THE DECREASE OF BODY FAT LEVELS IN SANGGAR SENAM RAI KOTA SAWAHLUNTO}

\begin{abstract}
This research is a quasi-experimental study that aims to determine how much influence the mix impact aerobic gymnastics has on decreasing body fat levels in Rai's gymnastics studio in Sawahlunto City.

The population in this study were 57 female members who were active in the aerobic gymnastics class at Sanggar RAI Studio in Sawahlunto City. Sampling uses purposive sampling technique with a sample of 14 people. The hypothesis proposed in this study is the significant effect of aerobics gymnastics impact on decreasing body fat levels in the Rai Gymnasium in Sawahlunto City. Based on the table above, the value of tcount $=38.00$, while the t table is 1,771 with a significant level $\alpha=0.05$ and $d k=14$ Based on the above decision, then $t$ count $>t$ table $(38>1,771)$. It can be concluded that the effect of mix impact aerobic exercise on the body fat content of Rai Sawahlunto gymnastics studio members.
\end{abstract}

Keywords: Mix Impact Aerobics, Body Fat Level. PENDAHULUAN

Hidup sehat dengan berat badan ideal adalah dambaan setiap wanita. Namun Pada kenyataan tidak semua wanita memiliki berat badan yang ideal dan untuk mendapatkannya mereka perlu melakukan berbagai macam upaya,salah satunya dengan menerapkan pola diet beragam dan
berolahraga.Beberapa penelitian menunjukan bahwa kelebihan berat badan telah menjadi masalah global, baik di Negara maju maupun berkembang.

Berdasarkan observasi di lapangan penulis melihat banyaknya perempuan atau ibu-ibu di sawahlunto memiliki kadar lemak yang berlebih (obesitas).Overweight yang 
biasa dikenal sebagai kegemukan, merupakan suatumasalah yang cukup merisaukan dikalangan ibu-ibu dan remaja. Obesitas atau kegemukanterjadi pada saat badan menjadi gemuk yang disebabkan penumpukan jaringanadipose secara berlebihan Diduga faktor penyebabnya nutrisi, karena kebiasaan masyarakat sawahlunto yang hobi mengkonsumsi makanan cepat saji. Teknologi sangat berpengaruh saat ini dalam penumpukan lemak, salah satunya kendaraan ibu-ibu lebih memilih menggunakan kendaraan dari pada berjalan kaki meskipun jarak tempuhnya dekat. Gen dapat juga mempengaruhi kadar lemak, karena gen memiliki pengaruh yang kuat pada berat badan seseorang, kegemukan dan obesitas cenderung terjadi karena faktor keturunan keluarga. Lingkungan juga berpengaruh dalam hal ini salah satunya kurangnya minat warga dalam menerapkan pola hidup sehat, seperti menjaga pola makan dan melakukan olahraga. Umur dapat menyebabkan penumpukan lemak, karena saat usia seseorang bertambah maka daya metabolisme tubuh akan semakin menurun. Kondisi fisik seseorang perlu melakukan olahraga dengan rutin untuk menjaga kadar lemak dalam tubuhnya. Terdapat berbagai macam olahraga yang dapat membakar, salah satunya senam aerobik.

Senam aerobik secara teratur akan dapat mencegah kegemukan dan dapat membentuk otot, tidak hanya itu dengan melakukan senam aerobik kita juga dapat memelihara elastisitas dan kesehatan kulit sehingga akan lamanya terjadi penuan dini seperti keriput dan kulit kering. Senam aerobik juga memiliki banyak jenis, diantaranya senam aerobik tanpa alat, didalam nya terdapat 9 kategori. Salah satunya mix impact (gabungan dari aerobik benturan tinggi dan ringan) dan low impact (aerobik benturan rendah).

Lemak adalah sekelompok ikatan organik yang terdiri atas unsur-unsurCarbon (C), Hidrogen $(\mathrm{H})$ dan Oksigen $(\mathrm{O})$, yang mempunyai sifat dapat larut dalam zat-zat pelarut tertentu (zat pelarut lemak) seperti petroleum benzena, ether. Lemak dalam tubuh berfungsi untuk cadangan tenaga, bantalan organ-organ tubuh tertentu, memberikan fiksasi organ tubuh tersebut seperti biji mata dan ginjal, isolasi sehingga panas tubuh tidak banyak keluar, mempertahankan tubuh dari gangguangangguan luar seperti pukulan atau bahanbahan berbahaya seperti zat kimia yang dapat merusak jaringan otot dan memberi garis-garis bentuk tubuh yang baik (LeaneSuniar, 2000 : 89).

Tubuh kita memiliki komposisi berupa masa lemak dan masa bebas lemak. Masa bebas lemak atau biasa disebut Fat Free Mass (FFM), terdiri dari massa protein (otot rangka dan otot non rangka) sebesar 19,4\%, mineral $6,8 \%$ dan cairan tubuh $73,8 \%$, serta mempunyai densitas $1,1 \mathrm{~g} / \mathrm{cm}^{3}$ (Amelia, 2009).

Selain FFM juga terdapat Lean Body Mass(LBM) yaitu bagian tubuh yang terdiri dari FFM dan masa lemak esensial, yang pada pria puncak kenaikan LBM terjadi pada usia 50 tahun, setelah itu terjadi penurunan terutama di atas usia 80 tahun. Besar penurunan LBM pada pria umumnya adalah $12 \%$, sedangkan pada wanita $19 \%$ (Firdaus, 2003).

Kualitas komposisi tubuh manusia dinyatakan dalam persentase lemak tubuh. Persentase lemak tubuh merupakan perbandingan massa tubuh berupa lemak dengan massa tubuh tanpa lemak. Seorang pria dikategorikan berbadan normal jika memiliki lemak badan $15-20 \%$, sedangkan pada wanita $20-25 \%$ (Irianto, 2004)

Menurut jonni (2011:12) gabungan dari latihan dari low impact dan high impact. Jenis latihan ini adalah perpaduan antara low dan high yang diperlakukansecara sistematis dan harmonis serta ritmis untuk meningkatkan endurance atau daya tahan secara keseluruhan sekaligus meningkatkan power bagi pelakunya. Bila dilakukan dalam waktu dan dosis yang tegas teratur, terukur latihan ini sangat cocok bagi pemula dan advance (Panduan Senam Diknas, 2001 : 10). 
Penurunan berat badan yang aman 0,5-1,0 Kg/minggu, sedangkan jumlah kalori yang dibakar setiap kali latihan kurang lebih 500-1000 kalori. Akan lebih baik lagi jika program penurunan berat badan disertai dengan program diet. Program latihan fisik yang berfungsi untuk pembakaran lemak tubuh memiliki ciri-ciri antara lain: gerakannya melibatkan otot-otot besar, dilakukan secara kontinyu dengan gerakan ritmis, takaran 46 MEDIKORA VOL. VX No. 1 April 2016 : 39-51 latihan: intensitas $65 \%-75 \%$ detak jantung maksimal, time (durasi) 20-60 menit setiap latihan.

\section{METODE (15\%)}

Penelitian ini dilaksanakan dengan Metode Eksperimen untuk melihat pengaruh dari latihan senam aerobik miximpactpada Sanggar Senam RAIkota Sawahlunto. Sampel berjumlah 15 orang dari populasi yang di tarik dengan teknik purposiv sampling yang mempertimbangkan usia, derajat kesehatan, dan kesediaan mengikuti program latihan. Pengukuran tebal lemak tubuh dengan menggunakan caliper skinfold yang diukur lipatan kulit triceps, subcapula, suprailiaca yang untuk selanjutnya diolah dengan menggunakan rumus untuk mengetahui persen lemak tubuh.Dalam menganalisis data penelitian digunakan terlebih dahulu dilakukan uji homogenitas untuk mengetahui data adalah homogen. Selanjutnya di teruskan dengan uji " $t$ " yaitu dengan rumus

\section{Pembahasan}

Berdasarkan tabel diatas didapatkan nilai $t_{\text {hitung }}=5$.18sedangkan $t_{\text {tabel }}$ sebesar 1.771 dengan taraf signifikan $\alpha=0.05$ dan $\mathrm{dk}=14$ Berdasarkan pengambilan keputusan diatas maka thitung > $\mathrm{t}_{\text {tabel }}(5.18>1.771)$. Dapat disimpulkan bahwa adanya efek dari latihan senam aerobikmix impact terhadap penurunan kadar lemak

$$
\mathrm{t}=\frac{\left\|\mathrm{z}_{1}-\mathrm{z}_{2}\right\|}{\sqrt{\frac{D^{2}-\left(\sum \frac{D^{2}}{n}\right)}{n(n-1)}}}
$$

\section{HASIL DAN PEMBAHASAN (70\%) Hasil Penelitian}

Hasil penelitian menunjukkan nilai ratarata kadar lemak tubuh anggota sanggar senam Rai Sawahlunto sebelum latihan senam aerobikmix impact adalah 29.85dengan standar deviasi \pm 4.67 , nilai minimum 18.70 dan nilai maksimum 39.00. Sesudah latihan senam aerobikmix impact adalah 27.81dengan standar deviasi \pm 4.89 , nilai minimum 16.50 dan nilai maksimum 38.50 .

kadar lemak tubuh anggota Sanggar Senam Rai Sawahlunto sebelum latihan senam aerobikmix impact dari 14 orang sampel dengan 1 orang (7.1\%) pada klasifikasi lemak rendah, 2 orang (14.3\%) pada klasifikasi lemak rata -rata, 7 orang $(50.0 \%)$ pada klasifikasi lemak diatas normal dan 4 orang $(28.6 \%)$ pada klasifikasilemak sangat tinggi.

kadar lemak tubuh anggota Sanggar Senam Rai Sawahlunto setelah latihan senam aerobikmix impact dari 14 orang sampel dengan 1 orang $(7.1 \%)$ pada klasifikasi lemak sangat rendah, 6 orang (42.9\%) pada klasifikasi lemak rata -rata, 5 orang $(35.7 \%)$ pada klasifikasi lemak diatas normal dan 2 orang $(14.3 \%)$ pada klasifikasilemak sangat tinggi.

tubuh anggota sanggar senam Rai Sawahlunto.

Lemak adalah sekelompok ikatan organik yang terdiri atas unsur-unsurCarbon (C), Hidrogen $(\mathrm{H})$ dan Oksigen $(\mathrm{O})$, yang mempunyai sifat dapat larut dalamzat-zat pelarut tertentu (zat pelarut lemak) seperti petroleum benzena, ether. Lemakdalam tubuh berfungsi untuk cadangan tenaga, bantalan organ-organ tubuh 
tertentu,memberikan fiksasi organ tubuh tersebut seperti biji mata dan ginjal, isolasi sehinggapanas tubuh tidak banyak keluar, mempertahankan tubuh dari gangguangangguanluar seperti pukulan atau bahanbahan berbahaya seperti zat kimia yang dapatmerusak jaringan otot dan memberi garis-garis bentuk tubuh yang baik (LeaneSuniar, 2000 : 89).

Massa lemak tubuh adalah massa lemak yang berada dalam jaringan adipose dan jaringan lainnya dalam tubuh. Massa lemak tubuh umumnya tersebar luas hampir di seluruh bagian tubuh dengan proporsi yang berbeda-beda, yaitu $50 \%$ pada subkutan, $45 \%$ sekeliling organ internal (rongga abdomen) atau yang biasa disebut dengan lemak visceral dan 5\% lainnya di jaringan intramuscular (Amelia, 2009).

Pada penelitian terlihat bahwa adanya efek dari latihan senam aerobikmix impact terhadap penurunan kadar lemak tubuh anggota Sanggar Senam Rai Sawahlunto, dimana didapatkan terjadinya penuruan nilai rata - rata ladar lemak setelah diberikan latihan senam. Menurut jonni (2011:12) gabungan dari latihan dari low impact dan high impact. Jenis latihan ini adalah perpaduan antara low dan high yang diperlakukansecara sistematis dan harmonis serta ritmis untuk meningkatkan endurance atau dayatahan secara keseluruhan sekaligus meningkatkan power bagi pelakunya. Biladilakukan dalam waktu dan dosis yang tegas teratur, terukur latihan ini sangat cocokbagi pemula dan advance dan dapat menurunkan kadar lemak (Panduan Senam Diknas, 2001 : 10).

Untuk mengurangi berat badan selain melakukan latihan harus dibantu dengan pemasukan kalori yang seimbang, karena dengan latihan aerobik membuat jantung dan paru-paru bekerja lebih baik, di samping mengurangi berat badan serta menjaga kebugaran. Guna mencapai titik kebugaran denyut nadi di usahakan meningkat ke denyut nadi $60-80 \%$ dari maksimum denyut nadi kelompok umur. Jika tidak tercapai maka latihan yang dilakukan belum memadai, lamanya waktu latihan serta tenaga perlu ditingkatkan.

Dalam penelitian ini data persentase lemak tubuh diperoleh dengan melakukan pengukuran tebal lemak di bawah kulit menggunakan alat skinfoldcaliper. Alat ini dilengkapi dengan ukuran yang akan menunjukkan ketebalan jaringan lemak di bawah kulit dengan cara mencubit menggunakan ibu jari dan jari telunjuk. Satuan ukurannya adalah milimeter (mm).

Berdasarkan hal ini maka menurut analisa peneliti terhadap penelitian ini adalah ditemukan bahwa adanyaefek dari latihan senam aerobikmix impact terhadap penurunan kadar lemak tubuh. Hal ini disebabkan karena adanya latihan senam yang teratur maka akan terjadi pembakaran lemak tubuh anggota senam sehingga dapat menyebabkan terjadinya penurunan akdar lemak. Dengan demikian untuk dapat menjaga agar kadar lemak menjadi normal atau seimbang maka maka perlu adanya latihan senam aerobikmix impactsecara rutin dan terprogram serta penuh tenaga (highitensity)pada peserta senam.

\section{KESIMPULAN (5\%)}

Bahwa adanya efek dari latihan senam aerobikmix impact terhadap penurunan kadar lemak tubuh anggota sanggar senam Rai Sawahlunto.

\section{DAFTAR PUSTAKA}

Alim, Abdul Dkk. 2011. Pengaruh Aktivitas Aerobik Terhadap Perubahan Penurunan Lemak Pada Sanggar Segar. Ilmu Keolahragaan Fakultas Ilmu Olahraga Universitas Negeri Yogyakarta. [Accesed 12 Januari 2014]

Bagus, Kisenda W. 2010. Mencapai Berat Badan Ideal dengan Diet.

http://www.scribd.com/doc/42004082/Berat -Badan-Ideal-dengan-Diet

Dewantari, Ni Made, dkk. 2011. Perbedaan Perubahan Berat Badan BerdasarkanFrekuensi Senam Aerobik. [di akses 15 Maret 2014]. Di 
unduh dari :poltekkesdenpasar.ac.id/files/JIG/V2N1/Dewant ari.pdf

Djamil, Rusdan. 1992. Erobik : Suatu Cara Untuk Meningkatkan Kesegaran Jasmani.Padang: Bagian Fisiologi FDOK UNAND.

Djoko Pekik Irianto. 2004.Pedoman Praktis Berolahraga Untuk Kebugaran dan Kesehatan. Yokyakarta: ANDI Offset.

Hartini. 2012. Perbedaan Pengaruh latihan senam aerobic high impact dan lowimpact terhadap penurunan persebtase lemak tubuh ditinjau dari body massindeks. Di unduh dari ..ejournal.utp.ac.id/index.php/JIS/artic le/view/159/145Di akses pada 22januari 2002.

http://hitachisulandari354.wordpress.com/20 08/09/17/pengertian-senam-aerobic/.

Jonni.2003. Senam Aerobic. Padang: Fakultas ilmu Keolahragaan Universitas Negeri Padang.

2011. Senam Aerobic. Padang: Fakultas Ilmu Keolahragaan Universitas Negeri Padang.

Kusuma. 1997. Gymnastic. Jakarta: Balai Pustaka.

Kusumaningtyas, Dian Nindita. 2011. Pengaruh Senam Aerobik Intensitas Ringandan Sedangterhadap Penurunan Persentase Lemak Badan. FisioterapiFakultas Ilmu Kesehatan Universitas Muhammadiyah Surakarta.
Lyne Brick. 2001. Bugar dengan Senam Aerobik. Jakarta: PT Raja Gasindo Persada

Manuaba, I.A. 2004. Dampak Buruk Obesitas. Online. Available at http://www.balipost.co.id/balipost/2004/3/7/cez.htm. [accessed $7 / 5 / 2011]$

Mumpuni, Y., dan Wulandari, A. 2010. Cara Mengatasi Kegemukan. Yogyakarta:Andi

Pate, et al. 1993. Dasar-dasar Ilmiah Kepelatihan. Semarang. IKIP Semarang. Press.

Sharkey Brian J. 2003. Kebugaran \& Kesehatan. Jakarta: PT. Raja Grafindo Persada.

Sharkey, B J. 2003. Kebugaran dan Kesehatan. Jakarta. PT Raja Grafindo Persada

\begin{tabular}{cc} 
2011. Kebugaran dan \\
\hline Kesehatan. Jakarta: Rajawali Pers.
\end{tabular}

Sumosardjuno, Sadoso. 1996. Sehat dan Bugar. Jakarta: PT Gramedia Pustaka Utama.

Theresia, Lydia. 2012. Hubungan Overweight dengan Peningkatan Kadar GulaDarah pada Pedagang Pusat Pasar Medan. Universitas Sumatera Utara.

Undang-Undang Tahun 2009 No 36 tentang kesehatan 